\title{
Effect of various levels of nitrogen, phosphorus and potash on the yield of French Bean
}

\author{
Qazi Shoaib Ali*, Shah Zeb, Ehtesham Jamil, Naveed Ahmed, \\ Muhammad Sajid, Sajid Siddique, Nazia Jan and Muhammad Shahid \\ Department of Horticulture, The University of Agriculture, Peshawar, Pakistan \\ *Corresponding author's email: qazi_hort@yahoo.com \\ Citation \\ Qazi Shoaib Ali, Shah Zeb, Ehtesham Jamil, Naveed Ahmed, Muhammad Sajid, Sajid Siddique, Nazia Jan and \\ Muhammad Shahid. Effect of various levels of Nitrogen, Phosphorus and Potash on the yield of French bean. Pure \\ and Applied Biology. Vol. 4, Issue 3, 2015, pp 318-322. http://dx.doi.org/10.19045/bspab.2015.43007
}

Received: 30/04/2015

Revised: 05/07/2015

Accepted: $11 / 07 / 2015$

\section{Abstract}

The experiment was conducted at the farm of Agricultural Research Station, Baffa (Mansehra) during August 2006 to monitor the effect of various levels of fertilizer treatments on plant height, number of branches plant ${ }^{-1}$, pod length, pod weight and pod yield of French bean variety (Paulista). The experimental results revealed that all the fertilizer treatments increased the plant height, number of branches plant ${ }^{-1}$, pod length, pod weight and pod yield of French bean significantly over control treatment. Maximum plant height $(39.03 \mathrm{~cm})$, number of branches $\operatorname{plant}^{-1}(18.25)$, pod length $(14.10 \mathrm{~cm})$, pod weight $(5.37 \mathrm{gm})$ and pod yield $\left(8.26 \mathrm{t} \mathrm{ha}^{-1}\right)$ were recorded in the treatments receiving $120 \mathrm{~kg} \mathrm{~N}, 90 \mathrm{~kg} \mathrm{P}_{2} \mathrm{O}_{5}$ and $90 \mathrm{~kg} \mathrm{~K}_{2} \mathrm{O} \mathrm{ha}^{-1}$. The economics of fertilizers were also worked out on the basis of current market prices and it was found that use of fertilizer was profitable. The cost benefit ratio ranged between 4.90 and 6.05.

Key words: Phaseolus vulgaris L; pod yield; growth parameters; fertilizers doses; NPK.

\section{Introduction}

French bean (Phaseolus vulgaris L.) belongs to the family Leguminoseae and is a prominent vegetable of Hazara Division. It is grown twice during a year, once as a fullseason crop in the month of March and secondly as an off-season crop in the month of August. Its green pods are cooked as a vegetable, being rich in protein and vitamins, calcium and iron. Islam et al., [1] reported that application of potassium exerted a beneficial effect on plant growth characteristics and also on the yield of bush beans. Prajapoti et al., [2] recorded higher pod yield of French bean from $120 \mathrm{~kg} \mathrm{~N} \mathrm{ha}^{-}$
1. Begum et al., [3] found that the highest fertilizer treatment (90-50-120) resulted in the highest pod length $(15.76 \mathrm{~cm})$, pod weight (82.33 gm plant $\left.^{-1}\right)$ and pod yield (13.99 q ha-1) of French bean. Sharma, [4] recorded maximum plant height, the number of branches plant ${ }^{-1}$ and green pod yield of French bean ha-1 with $120 \mathrm{~kg} \mathrm{~N} \mathrm{ha}^{-1}$. He also recorded maximum plant height and the number of branches plant ${ }^{-1}$ with $60 \mathrm{~kg} \mathrm{P} \mathrm{ha}^{-}$ 1. The interaction effect between $\mathrm{N}$ and $\mathrm{P}$ was significant. Highest pod yield was obtained at a treatment combination of 120 $\mathrm{kg} \mathrm{N}$ and $60 \mathrm{~kg} \mathrm{P} \mathrm{ha}^{-1}$. Dhanjal et al., [5] found significantly higher branches plant $^{-1}$ at 
$120 \mathrm{~kg} \mathrm{~N} \mathrm{ha}^{-1}$. Singh, [6] got maximum pod length form the application of $125 \mathrm{~kg} \mathrm{~N} \mathrm{ha}^{-1}$. Singh and Singh [7] reported that the yield and yield component values of French bean increased with increasing $\mathrm{N}$ rates, but were generally highest with $80 \mathrm{~kg} \mathrm{P} \mathrm{ha}^{-1}$. Sirnivas and Naik, [8] reported that nitrogen and phosphorus fertilization of French bean resulted in increased pod yield. Sangakara, [9] found that the vegetative growth and most yield components of French bean increased significantly upto $100 \mathrm{~kg} \mathrm{~K}_{2} \mathrm{O}$ ha $^{-}$ ${ }^{1}$. Neuvel et al., [10] found that pod yield of snap beans were 12.9, 13.9, 15.0 and 15.8 ton $\mathrm{ha}^{-1}$ with $0,50,100$ and $150 \mathrm{~kg} \mathrm{~N}^{-1}$ respectively. Chandra et al., [11] found that the plant growth and yield of French bean increased with the increasing rates of nitrogen and phosphorus. Ivano et al., [12] reported that the pod yield of French bean was increased with the increase $\mathrm{N}$ levels upto $150 \mathrm{~kg} \mathrm{ha}^{-1}$. Continuous cropping without the proper application of plant nutrients to the soil causes a substantial decrease in crop yield. Supply of plant nutrients, especially nitrogen, phosphorus and potash through fertilizer application is one of the best methods to increase the French bean growth and yield. The present study was, therefore conducted to monitor the effect of various levels of nitrogen, phosphorus and potash on the growth parameters and green pod yield of French bean and also to furnish economically sound fertilizer recommendations for French bean production in District Mansehra.

\section{Materials and Methods}

The experiment was conducted at the farm of Agricultural Research Station, Baffa during August 2006 in District Mansehra that lies lies from $34^{\circ}-14^{\prime}$ to $35^{\circ}-11^{\prime}$ north latitudes and $072^{\circ}-49^{\prime}$ to $074^{\circ} 08^{\prime}$ east longitudes [13]. The soil under test was silt loam, having $0.82 \%$ organic matter, $0.041 \%$ nitrogen, $9 \mathrm{mg} \mathrm{kg}^{-1}$ available phosphorus, $115 \mathrm{mg} \mathrm{kg}$-1 available potassium, 2.2\% $\mathrm{CaCO}_{3}$ and $\mathrm{pH}$ of 7.2. The design of the experiment was randomized complete block with 4 replications. There were 6 treatments in the experiment (Table-1). Each plot (10.8 $\mathrm{m}^{2}$ ) consisted of 6 rows, each 3 meter long and $60 \mathrm{~cm}$ apart. Plant to plant distance was $20 \mathrm{~cm}$. Total 15 plants were kept in each row. Out of 15, 08 plants were tagged as a sample plants for data collection. Before sowing of crop, the land was prepared thoroughly and nitrogen, phosphorus, and potash were applied in the form of urea, triple super phosphate and potassium sulphate respectively. All phosphorus, potash and $1 / 2$ nitrogen was applied at the time of sowing while remaining $1 / 2$ nitrogen was applied after one month of sowing. The variety used was Paulista. All the recommended cultural practices like weeding and irrigation was practiced uniformly in all the treatments as per requirements. The crop was irrigated through flood system according to the soil moisture condition. The whole crop was harvested after a period of 120 days. During the course of experiment, the data was recorded on plant height $(\mathrm{cm})$ at maturity, number of branches plant ${ }^{-1}$, pod length $(\mathrm{cm})$, pod weight $(\mathrm{gm})$ and pod yield $\mathrm{tha}^{-1}$.

\section{Statistical Procedure}

Data collected for various characteristics were analyzed statistically using Fisher's analysis of variance technique [14]. All the treatments were compared by Duncan's Multiple Range test at 5\% probability level [15]. 
Pure Appl. Bio., 4(3): 318-322, September - 2015

Table-1. Fertilizer treatments used in the experiment

\begin{tabular}{|c|c|c|c|}
\hline \multirow{2}{*}{ Treatments } & $\mathrm{N}\left(\mathrm{Kg} \mathrm{ha}^{-1}\right)$ & $\mathrm{P}_{2} \mathrm{O}_{5}\left(\mathrm{Kg} \mathrm{ha}^{-1}\right)$ & $\mathrm{K}_{2} \mathrm{O}\left(\mathrm{Kg} \mathrm{ha}^{-1}\right)$ \\
\hline $\mathrm{T} 1$ & 0 & 0 & 0 \\
\hline $\mathrm{T} 2$ & 60 & 60 & 60 \\
\hline $\mathrm{T} 3$ & 90 & 60 & 60 \\
\hline $\mathrm{T} 4$ & 90 & 90 & 60 \\
\hline T5 & 90 & 60 & 90 \\
\hline T6 & 120 & 90 & 90 \\
\hline
\end{tabular}

\section{Results and Discussion}

The data presented in (Table-2) show the effect of various fertilizer treatments on the plant height, number of branches plant ${ }^{-1}$, pod length, pod weight and pod yield $\mathrm{ha}^{-1}$. It is evident from the data that all the fertilizer treatments increased the plant height, number of branches plant ${ }^{-1}$, pod length, pod weight and pod yield ha ${ }^{-1}$ significantly over control treatment. By comparing the various fertilizer treatments with one another, maximum plant height of $39.03 \mathrm{~cm}$ was observed in T6 (120-90-90), followed by $37.75 \mathrm{~cm}$ in T4 (90-90-60). These results are in agreement with the findings of Sharma (2001). Maximum number of branches plant ${ }^{-}$ ${ }^{1}$ i.e. 18.25 and 17.50 were found in T6 (12090-90) and T4 (90-90-60) respectively. These results are in conformity with the findings of $[4,5]$. Maximum pod length of $14.10 \mathrm{~cm}$ was observed in T6 (120-90-90), followed by $13.78 \mathrm{~cm}$ in T4 (90-90-60). These results are in agreement with the findings of $[3,6]$. Similarly maximum pod weight (5.37 gm) was recorded in T6 (12090-90), followed by (5.26 gm) in T4 (90-90$60)$. The highest pod yield of $8.26 \mathrm{t} \mathrm{ha}^{-1}$ was recorded in T6 (120-90-90), followed by T4 (90-90-60), wherein pod yield was $7.82 \mathrm{t} \mathrm{ha}^{-}$ ${ }^{1}$. These results can be attributed to the fact that the French bean responded well to the enhanced doses of fertilizers. These increases in the yield component may be the result of better utilization of NPK which resulted in increased biosynthesis of the photosynthates and ultimately the yield. These results are in consonance with the [24, 7, 9-12].

Economics of fertilizer practices

Economic feasibility of the fertilizer practices should be an essential element of studies aimed at improving crop productivity. Basically, the farmer is an economist and he adopts only those improved practices which are more paying and easily workable. On the basis of current market prices of fertilizer and French bean, the obtainable income from the additional yield was worked out. Table- 3 reflects the comparative economics of various fertilizer levels on French bean. Evidently, there could be no additional income from the control treatment which received no fertilizer. The cost benefit ratio from different fertilizer application varied between 1:4.90 to1:6.05. All the fertilizer levels were found profitable over control, indicating that the use of fertilizer in judicious amounts will always remain a profitable proposition for the French bean growers. Treatment-4 showed the highest cost benefit ratio $(1: 6.05)$, followed by $\mathrm{T} 3$ (1:5.95).

All the fertilizer treatments have shown marked yield increase. However, the better and economically sound response was given by $\mathrm{T} 4$, receiving $90 \mathrm{~kg} \mathrm{~N}$ plus $90 \mathrm{~kg} \mathrm{P}_{2} \mathrm{O}_{5}$ and $60 \mathrm{~kg} \mathrm{~K}_{2} \mathrm{O} \mathrm{ha} \mathrm{h}^{-1}$ under the soil conditions prevailing in Mansehra District. 
Table-2 Effect of various fertilizer treatments on the growth and yield of French bean. (Figures are average of 4-replications)

\begin{tabular}{|c|c|c|c|c|c|c|}
\hline Treatments & $\begin{array}{c}\mathrm{N}-\mathrm{P}_{2} \mathrm{O}_{5}-\mathrm{K}_{2} \mathrm{O} \\
\mathrm{Kg} \mathrm{ha}^{-1}\end{array}$ & $\begin{array}{c}\text { Plant } \\
\text { height } \\
(\mathrm{cm})\end{array}$ & $\begin{array}{c}\text { Number of } \\
\text { branches }^{-1} \\
\text { plant }^{-1}\end{array}$ & $\begin{array}{l}\text { Pod length } \\
\text { (cm) }\end{array}$ & $\begin{array}{l}\text { Pod weight } \\
\text { (gm) }\end{array}$ & $\begin{array}{c}\text { Pod yield } \\
\left(t \text { ha }^{-1}\right)\end{array}$ \\
\hline $\mathrm{T} 1$ & $0-0-0$ & $33.90 \mathrm{~d}$ & $14.25 \mathrm{c}$ & $10.85 \mathrm{c}$ & $3.79 \mathrm{~d}$ & $4.41 \mathrm{~d}$ \\
\hline $\mathrm{T} 2$ & $60-60-60$ & $36.33 \mathrm{c}$ & $16.00 \mathrm{~b}$ & $13.08 \mathrm{~b}$ & $4.80 \mathrm{c}$ & $6.59 \mathrm{c}$ \\
\hline T3 & $90-60-60$ & $36.90 \mathrm{c}$ & $17.00 \mathrm{ab}$ & $13.53 \mathrm{ab}$ & $5.13 \mathrm{~b}$ & $7.34 \mathrm{bc}$ \\
\hline $\mathrm{T} 4$ & $90-90-60$ & $37.75 \mathrm{~b}$ & $17.50 \mathrm{a}$ & $13.78 \mathrm{ab}$ & $5.26 \mathrm{ab}$ & $7.82 \mathrm{ab}$ \\
\hline T5 & $90-60-90$ & $37.58 \mathrm{~b}$ & $17.25 \mathrm{ab}$ & $13.65 \mathrm{ab}$ & $5.19 \mathrm{ab}$ & $7.50 \mathrm{ab}$ \\
\hline T6 & $120-90-90$ & $39.03 \mathrm{a}$ & $18.25 \mathrm{a}$ & $14.10 \mathrm{a}$ & $5.37 \mathrm{a}$ & $8.26 \mathrm{a}$ \\
\hline \multicolumn{2}{|c|}{ L.S.D at 5\% } & 0.82 & 1.28 & 0.69 & 1.89 & 0.80 \\
\hline
\end{tabular}

Means followed by the same letter (s) do not differ significantly from one another at 5\% probability level, using LSD test.

Table-3. Comparative economics of various fertilizer treatments on French bean.

\begin{tabular}{|c|c|c|c|c|c|}
\hline $\begin{array}{l}\text { Treatments } \\
\mathrm{N}-\mathrm{P}_{2} \mathrm{O}_{5}-\mathrm{K}_{2} \mathrm{O} \\
\mathrm{kg} \mathrm{ha}^{-1}\end{array}$ & $\begin{array}{l}\text { Cost of } \\
\text { Fertilizer } \\
\text { (Rs) }\end{array}$ & $\begin{array}{l}\text { Average yield } \\
\left(\mathrm{t} \mathrm{ha} \mathrm{h}^{-1}\right)\end{array}$ & $\begin{array}{l}\text { Additional Yield } \\
\text { over control (t ha- } \\
{ }^{1} \text { ) }\end{array}$ & $\begin{array}{l}\text { Value of Add. Yield@Rs } \\
15000 \mathrm{t}^{-1}\end{array}$ & Cost benefit ratio \\
\hline T1 (0-0-0) & & 4.41 & & & \\
\hline T2 (60-60-60) & 6668 & 6.59 & 2.18 & 32700 & $1: 4.90$ \\
\hline T3 $(90-60-60)$ & 7385 & 7.34 & 2.93 & 43950 & $1: 5.95$ \\
\hline T4 (90-90-60) & 8442 & 7.82 & 3.41 & 51150 & $1: 6.05$ \\
\hline T5 (90-60-90) & 8945 & 7.50 & 3.09 & 46350 & $1: 5.18$ \\
\hline Т6(120-90-90) & 10719 & 8.26 & 3.85 & 57750 & $1: 5.39$ \\
\hline
\end{tabular}

\section{References}

1. Islam MS, Haque MM, Khan MM, Hidaka T \& Karim MA (2004). Effect of fertilizer potassium on growth, yield and water relations of bush bean (Phaseolus vulgaris L.) under water stress conditions. Japanese Journal of Agriculture. 48(1):1-9.

2. Prajapoti MP, Patel HA, Prajapati BA \& Patel LR (2004). Studies of nutrient uptake and yield of French bean (Phaseolus vulgaris L.) as affected by weed control methods and nitrogen levels. Legume Res. 27(2): 99-102.

3. Begum A, Ahad A, Kaisar MO, Islam MM \& Anam MK (2003). Effect of sowing dates and fertilizer treatments on the reproductive variability of French bean (Phaseolus vulgaris). Pak. J. of Biological Sci. 6(22): 1897-1901.

4. Sharma SK (2001). French bean green pod and seed production as influenced by nitrogen and phosphorus application.
Annals of Agricultural Research. 22(1): 130-132.

5. Dhanjal R, Parkash O \& Ahlawat SPI (2001). Response of French bean (Phaseolus vulgaris L.) varieties to plant density and nitrogen application. Indian J. Agron. 46(2): 277-281.

6. Singh RV (2000). Response of French bean (Phaseolus vulgaris L.) to plant spacing and nitrogen, phosphorous fertilization. Indian J. Hort. 57(4): 338341.

7. Singh AK \& Singh SS (2000). Effect of planting dates, nitrogen and phosphorus levels on yield contributing factors in French bean. Legume Research. 23(1): 33-36.

8. Srinivas K \& Naik LB (1988). Response of vegetable French bean (Phaseolus vulgaris $L$.) to nitrogen and phosphorus fertilization. Indian J. Agril. Sci. 58: 707-708. 
9. Sangakkara UR (1996). Response of French bean (Phaseolus vulgaris L.) to rate and ratio of potassium fertilizer application. Pertanika Journal of Tropical Agricultural Science. 19(1): 6167.

10. Neuvel JJ, Floot HWG, Postma S \& Evers MAA. (1994). Research on reducing nitrogen fertilizer application to snap beans (Phaseolus vulgaris L.) by inoculation with Rhizobium phaseoli. Verslag Proefstation Voor de Akkerbouw en de Groenteteelt in de Vollegrond. (168): 120 pp.

11. Chandra R, Rajput CBS, Singh KP \& Singh SJP (1987). A note on the effect of nitrogen phosphorus and Rhizobium culture of the growth and yield of French bean (Phaseolus vulgaris L.) cv.
Contender. Haryana J. Hort. Sci. 16: 146-147.

12. Ivanov L, Rankov V, Veler B, Manuelyan KH, Porayajov I, Benevshi M \& Petrove R (1987). Optimizing mineral fertilization in commercial green bean production. Rasteniev "dui-Nauk" 24: 45-49.

13. Waleed MA, Nisar, Ak, Bilal M (2004). Effect of irrigation interval on the growth and yield of potato. Thesis, Uni. Agri. Peshawar.

14. Steel RGD and JH Torrie (1980). Analysis of co variance. In: Principles and Procedure of Statistics: Biometric Approach. p. 401-437. McGraw Hill Book Co., Inc., NY, USA.

15. Duncan DB (1955). Multiple range and multiple F-tests. Biometrics, 11: 1-42. 